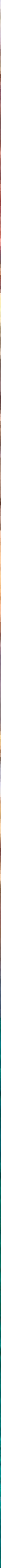




\section{Tras los Trazos Históricos del Bicentenario Nicaragüense}

After the Historical Traces of the Nicaraguan Bicentennial

\section{RESUMEN}

En conmemoración del bicentenario de Centroamérica, nace este artículo con el objetivo fundamental, de analizar los contenidos políticos y filosóficos que nos han trasmitido durante estos 200 años de independencia del imperio hispánico. Para ello, nos remontaremos a la antigua Capitanía General de la Asunción de Guatemala, virreinato español, que vivió su independencia, sin derramar ni una gota de sangre. Suceso completamente diferente a las luchas que emprendió México o Suramérica, donde se libraron guerras sangrientas como la que protagonizaron Morelos, Simón Bolívar, José Antonio Sucre, Artigas, O’Higgins, San Martín, Céspedes o José Martí en Cuba. La historia de Centroamérica, ha sido muchas veces falseada por intereses políticos y religiosos, sumado a que gran parte de esa historiografía regional, se ha visto marcada, con amplios matices de colonialismo, chouvinismo, fetichismo y neocolonialismo, casualmente muchas de las imprecisiones histórica en el continente americano, radica en alimentar la llamada "maldición de malinche" y así justificar los antecedentes históricos de la colonia y la modernidad. Habiendo cientos de documentos, que exaltan repetitivamente la superioridad europea, ante la supuesta tiranía e idolatría autóctona americana, siendo abundante los autores que se apasiona con el romanticismo greco-romano, para así justificar su xenofilia y xenolatría política, dando paso a la construcción o concepción de la modernidad hegemónica, bajo todos sus matices eurocéntricos. En la provincia de Nicaragua, de los pocos intelectuales que se atrevieron a "rebelarse", al sistema colonial fue Miguel Larreynaga, junto al hondureño José Cecilio del Valle, quienes redactaron el acta de independencia, dando lugar al gobierno presidido justamente por el español Gabino Gainza; quien además de convertirse en presidente, fue llamado "insigne" de la independencia de Centroamérica, a pesar que claramente obedecía siempre al interés peninsular y criollo, que buscaba evitar el pago de tributos a la corona española. Casualmente, así se empezó a construir los hechos históricos, que marcó la independencia centroamericana, construyendo el concepto de "próceres" de la emancipación a los mismos españoles, el mejor caso es del mencionado señor "Gabino Gainza".

\section{ABSTRAC}

In commemoration of the bicentennial of Central America, this article was born with the fundamental objective of analyzing the political and philosophical contents that have been transmitted to us during these 200 years of independence from the Hispanic Empire. To do this, we will go back to the former Captaincy General of the Assumption of Guatemala, Spanish viceroyalty, which lived its inde- Bicentennial, National Identity, Central pendence, without shedding a drop of blood. Completely different from the stru- American Union and Struggle for the ggles that Mexico or South America waged, where bloody wars were fought like second Independence. the one that Morelos, Simón Bolívar, José Antonio Sucre, Artigas, O'Higgins, San Martín, Céspedes or José Martí carried out in Cuba.

\section{PALABRAS CLAVE}

Bicentenario, Identidad Nacional, Unión Centroamérica y Lucha por la segunda Independencia. 
The history of Central America has been distorted many times by political and religious interests, in addition to the fact that a large part of that regional historiography has been marked, with broad nuances of colonialism, chouvinism, fetishism and neocolonialism, coincidentally many of the historical inaccuracies in the American continent lies in feeding the so-called "malinche curse" and thus justifying the historical antecedents of the colony and modernity. There are hundreds of documents, which repeatedly exalt European superiority, before the supposed tyranny and autochthonous American idolatry, being abundant the authors who are passionate about Greco-Roman romanticism, in order to justify their xenophilia and political xenolatry, giving way to the construction o conception of hegemonic modernity, under all its Eurocentric nuances. In the province of Nicaragua, one of the few intellectuals who dared to "rebel" against the colonial system was Miguel Larreynaga, together with the Honduran José Cecilio del Valle, who drafted the act of independence, giving rise to the government chaired precisely by the Spanish Gabino Gainza; who, in addition to becoming president, was called a "distinguished" of the independence of Central America, despite the fact that he clearly always obeyed the peninsular and Creole interest, which sought to avoid paying tribute to the Spanish crown. Coincidentally, this is how the historical events began to be built, which marked the Central American independence, building the concept of "heroes" of the emancipation of the Spaniards themselves, the best case is of the aforementioned Mr. "Gabino Gainza".

\section{Introducción.}

La independencia de la corona española implicó la fundación de nuevas naciones, nuevas estructuras organizativas, territoriales, identitarias y paradigmas políticos, decir con toda claridad y certeza cuando se liberó la Capitanía General de Guatemala, suele ser una tarea sencilla, tanto para los gobiernos como para los intelectuales, maestros de secundaria, primaría, universidad y residentes actuales de los cinco países centroamericanos, que aceptan y celebran el 15 de septiembre como el día de la independencia, porque en esa fecha, las autoridades de la ciudad capital del entonces virreinato de la Asunción de Guatemala, se juntaron y aceptaron iniciar el proceso de la separación de España, en el contexto de una Unidad Centroamericana o ante una posible anexión a México.

Entre 1821 y 1823, entre actas, pactos y acuerdos múltiples de comunidades de toda Centroamérica, enfrentaron el proceso independentista con palabras en vez de armas, después del acta independentista, le siguió un referéndum municipal y regional para votar la anexión (o no) a México a finales de 1821, y finalmente un decreto emitido por un congreso constituyente a mediados de 1823, que dispuso la independencia absoluta de las provincias de la antigua Capitanía General y su reorganización en las Provincias Unidas de Centro América, precursora de la república Federal de Centro América, una federación que existió entre 1824 a 1839, entonces vemos que no es fácil determinar el "momento exacto" de la independencia de Nicaragua.

La mitificación de estos hechos, formaron parte del contenido político que se trasmitió, de generación en generación, durante los actos de celebración de la independencia de Nicaragua, entre 1866 y 1895 , podemos dividir dos periodos, el primero corresponde a los años de 1866 a 1875, donde la libertad había traído la igualdad entre los nicaragüenses, pero estos tenían que practicar el patriotismo y el trabajo con el fin de cimentar la estabilidad política, mientras continuaba sangrando la herida de la añorada Federación centroamericana, misma que palpitaba en el pecho de cientos de hombres y mujeres de todas las clases sociales y origen étnico. 
El segundo momento, es entre 1877 y 1895 , con los discursos conmemorativos del 15 de septiembre, donde se destacó, los conceptos políticos del Estado nación y el papel "libertador" de la educación, promoviendo la unidad nacional y sobre todo la regeneración étnica entre las y los nicaragüenses, pues se rescataba el protagonismo y la valentía del héroe nacional José Dolores Estrada, mientras los Flecheros Matagalpa que combatieron a su mando, continuaban siendo omitidos por ser "indios", por otro lado, se exaltó el progreso económico y la estabilidad política traída por los gobiernos conservadores. Estas peroraciones sirvieron para manifestar una visión clasista y mantener la forma de dominación imperante. Por otra parte, los textos publicados por la prensa nicaragüense sobre las celebraciones del 15 de septiembre durante el período 1903-1928, exponen las diversas influencias político-culturales que existían en esa época para tratar el tema de la identidad nacional y analizar los principales problemas por los que atravesaba Nicaragua, principalmente el de la ocupación estadounidense. Estas posturas iban del nacionalismo, al antiimperialismo y al unionismo. Cuando hoy, en el siglo veintiuno, nos damos a la tarea de repensar las Independencias de América, lo hacemos con el convencimiento de que hay muchísimas lecciones aprendidas durante 200 años. Aprendizajes que representan un cúmulo de conocimientos propios americanos, que comprendidos desde el propio espacio pueden contribuir a renovar la imaginación del pasado y del futuro del país.

\section{La Independencia Reconstituida}

El gobierno de Gabino Gainza se enfocó en discutir la anexión o no al proyecto de Agustín de Iturbide, que consistía la Unión de Centroamérica con México, siendo los conservadores guatemaltecos los principales defensores de tales ideas, para ello, Clan Aycinena influyó en el presidente Gabino Gainza, para aceptar la propuesta de unificar la región centroamericana con el imperio mexicano de Agustín Iturbide, al mismo tiempo, Agustín en su delirio de emperador envió una poderosa división armada de militares del ejército de México rumbo a Ciudad Antigua. El gobierno de Gainza contestó con una carta del 03 de diciembre de 1821, que era necesario consultar a diversos cabildos centroamericanos, para dar una respuesta a la cuestión, culminando su contestación sugirió elocuentemente que:

Espero que vuestra excelencia dejará en suspensos sus decisiones, y detendrá la marcha de su división armada, hasta la llegada de mi respuesta que le enviaré por correo el 03 de enero de 1822 ”.

Para el 05 de enero de 1822 Gainza, pudo remitir su conteo aún incompleto, de 200 ayuntamientos tenía como resultados, 32 cabildos aceptaban la anexión, pero 104 bajo condiciones claras y 2 se oponían por completo, mientras que otros 21 ayuntamientos decían que sólo podía ser debatido por el congreso que debía de unirse en marzo. Cabe mencionar, que la ocurrencia de Gainza, de consultarle a los cabildos, violaba la disposición número 2 del acta de la Independencia del 15 de septiembre de 1821, que rezaba el "Congreso que debe decidir el punto de independencia general absoluta y fijar en caso de acordarla, la forma de gobierno y ley fundamental que debe regir".

Entonces desde 1821 a 1839, vamos a encontrar un sinnúmero de encargados de la presidencia, más golpes de estados y presidentes temporales electos por el Congreso, dicha inestabilidad política, sumado al descontrol administrativo, los intereses de la oligarquía, la concentración del poder en Guatemala y las contradicciones de clase entre la burguesía incipiente de ambas regiones marcarían el fin de la propuesta del proyecto de "República Federal de Centroamérica, sin embargo, este escenario es la antesala de lo que sería después cada uno de las provincias centroamericanas. 
Asimismo, la integración de centroamericana como un espacio económico y político no fue posible, en alguna medida, por la fragmentación del istmo, desde la administración española, por ejemplo, una buena parte del pacífico desde Honduras, Nicaragua hasta Costa Rica, mantenía nexos con Panamá; mientras El Salvador, el norte de Nicaragua, con el oriente de Honduras conformaban otro espacio económico con Guatemala, dicha división es desde los orígenes de la invasión y colonización del territorio centroamericano.

\begin{tabular}{|l|l|l|}
\multicolumn{3}{|c|}{ Jefes de Estado de la Republica Federal de Centroamérica } \\
\hline Gabino Gainza & Nacionalidad & Feriodo \\
\hline 1ero y 2do Triunvirato & Español & $1821-1822$ \\
\hline Manuel Jose de Arce & Centroamericano & $1823-1825$ \\
\hline Francisco Morazán & Salvadoreño & $1825-1829$ \\
Trancisco Morazán & Hondureño & $1830-1834$ \\
\hline
\end{tabular}

Elaborado por el Autor

En medio de las discusiones, guerras intestinas, contradicciones regionales, intereses comerciales, cambios de capital, desconocimiento de los presidentes y obsesión de poder de la oligarquía y burguesía incipiente centroamericana, fracasaría el proyecto de la Federación Centroamericana, imponiéndose los intereses mezquinos de las clases dominantes, sobre las clases dominadas política y económicamente. Hasta que cada una de las cinco provincias de Guatemala, El Salvador, Honduras, Nicaragua y Costa Rica, tomaron la decisión de separarse de la república centroamericana 17 años después de su fundación.

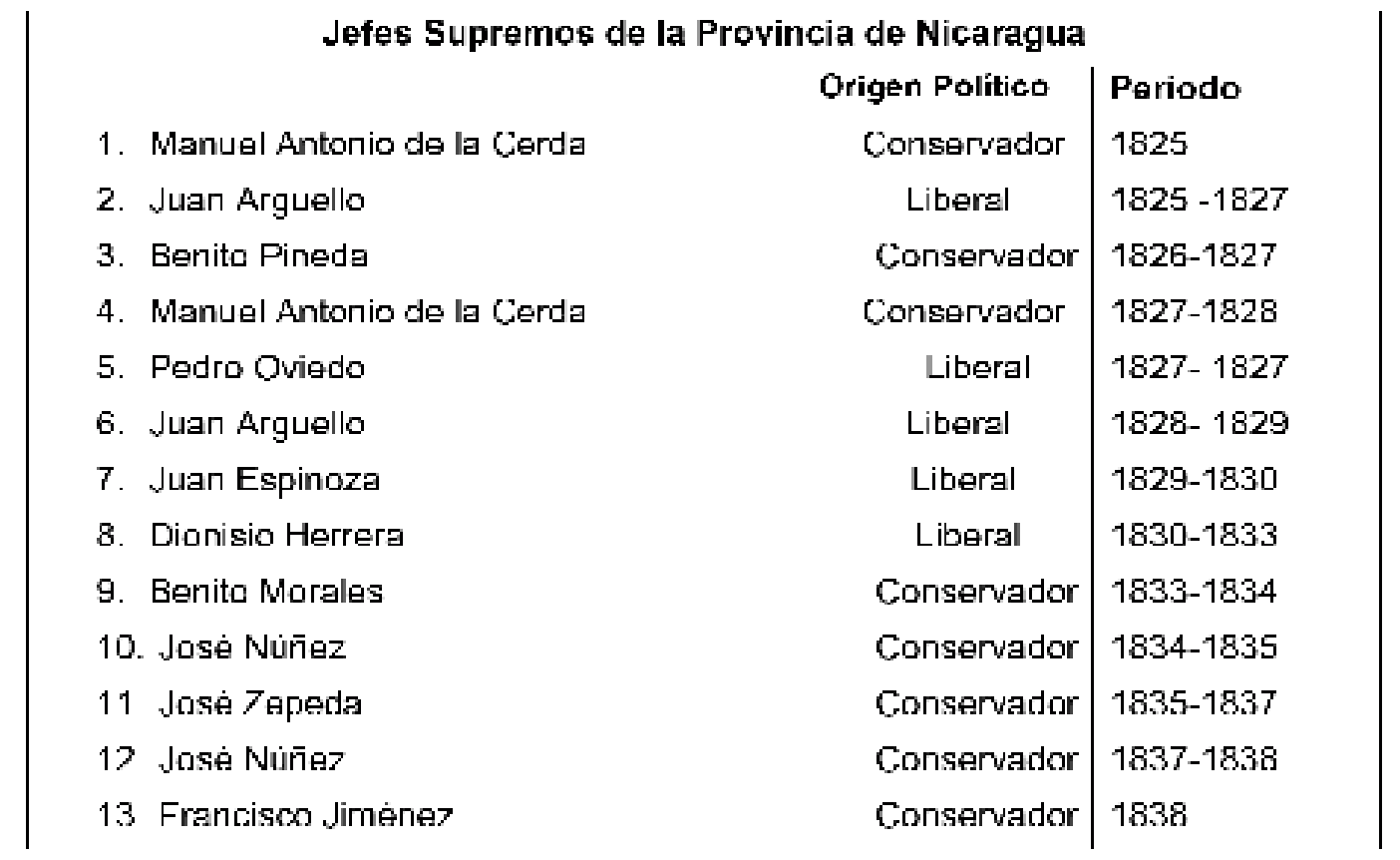


Los políticos centromericanos atribuian la poca independencia y solides de los gobiernos de esa época, pensando que con una segunda independencia las cosas podrían ser manejadas de mejor manera, para las clases oligárquicas de cada uno de los cinco países de la región. Asimismo, con respecto a la formación del Estado-nación en Nicaragua, la independencia surgió en medio de ideologías colonialistas y mercantilistas, la cual apenas culminó en el establecimiento de una identidad nacional en el país.

Por otra parte, la rivalidad entre Granada y León se intensificó por lo que no se pudo ejercer la soberanía sobre la mitad oriental del país, que se sometió al control de los británicos. En este contexto, la idea de una nación nicaragüense, encontró terreno bastante inflexible para que se pudiera crear una identidad nacional a partir de los sectores populares. Podían ser parte de la nación nicaragüense, pero no iban a tener ningún papel constitutivo en su formación. La organización de una identidad nacional en Nicaragua, en el siglo XIX, no fue un proceso que se impuso de arriba hacia abajo, en el que las élites impusieron su proyecto de nación, sobre los sectores subalternos, más bien lo que sucedió, fue que los grupos de poder y los sectores populares negociaron el significado del Estado y de la identidad nacional desde posiciones de poder desiguales. Aunque la aristocracia utilizó la coerción directa para crear y mantener el Estado, su utilización prolongada condujo inevitablemente a la negación de la legitimidad del Estado y al aumento de la influencia de identidades colectivas de carácter no nacional, es decir extranjeras (Wolfe, 2007, p.7-9).

\section{La Naciente República de Nicaragua}

Un 30 de abril de 1839 se conformó una Asamblea Nacional Independiente para darle vida jurídica a la República de Nicaragua, declarándose "libre y soberana e independiente", eligiendo como su primer director supremo o jefe de Estado, quien había sido el último representante de la provincia centroamericana don José Núñez. Este sera, el origen de la formación del Estado-Nación, que comenzó durante el período de los Treinta y Cinco Años Conservadores (1858-1893), una vez superada la anarquía política que caracterizó al país en sus primeros treinta y siete años de vida independiente. Sin embargo, los conservadores manifestaron una postura política excluyente con las clases populares, tal hecho se refleja en la constitución de 1858, debido a que en ella sólo eran considerados como ciudadanos los que poseían bienes y capitales. La Carta Magna, solo otorgaba el derecho a votar a 570 personas, de esta manera, los primeros actos de celebración del aniversario de la independencia en Nicaragua se realizaron en 1866, durante el período político conservador, debido a que durante los períodos de la anarquía (1821-1857), no existió la estabilidad política y la capacidad económica para festejar esta fecha patria (Lanuza, 1976).

Para Frances Kinloch (2001), la derrota del filibustero William Walker, no se convirtió en una posibilidad de exaltar la imagen de los nicaragüenses como conjunto social. Al contrario, se reconoció la propia inferioridad étnica, donde se descubrió el peso de la imagen atribuida a los pueblos del trópico, por todo el pensamiento antropológico ilustrado y la revolución industrial (las ideas de la degradación de "la raza americana" y su incapacidad para autogobernarse), e incluso la influencia de la tesis sobre la superioridad de la raza anglosajona, esgrimida por los propagandistas del Destino Manifiesto. Sin embargo, las élites políticas refirieron dicha inferioridad a los sectores subordinados y se reservó para sí el rol de diseminadores de la civilización europea, aunque después de casi treinta años de transitar en la anarquía la élite política comenzó a perder la esperanza en cuanto a su capacidad para instituir gobiernos estables, lo cual atribuyeron a la herencia cultural española e, incluso, a la sangre de sus ancestros (p.198).

En este sentido debo señalar que, el festejo de las fiestas patrias en Nicaragua, fue construido en las últimas dos décadas del siglo XIX, orientado desde el sistema educativo, de donde aprendimos a fomentar el amor por la patria. Dando origen a los actos escolares, donde se efectuaban rituales con el objetivo de festejar los momentos históricos más relevantes de la sociedad nacional interpretados a la luz del momento. 
Esto lo señalan autores como Gellner (1983), Bertoni (1992), Blázquez (2000) y Mc Laren (1995). De esta manera, se fue construyendo paulatinamente un sentimiento de nacionalismo, fortalecido después de la expulsión de los filibusteros norteamericanos, dicho contexto, favoreció las transformaciones económicas, y las decisiones políticas del nuevo Estado nicaragüense, quien abrazó por completo el auge del cultivo del café, para dar inicio a una política agraria injusta para los campesinos e indígenas, asimismo, se inició a organizar las instituciones financieras, la creación de una moneda nacional y el mejoramiento de las vías de comunicación entre las regiones.

Managua adquirió un papel clave por su posición geográfica al estar en el centro de la intersección de la red de caminos, ferrocarriles y vías fluviales que ayudaban al transporte de los granos. Todo esto hizo tomar consciencia a la oligarquía de la necesidad de un Estado nacional (Merlet, 1990). Sin embargo, a como dice el historiador norteamericano Jeffrey Gould (1995) uno de los pilares en la construcción de la nación nicaragüense, es la noción de que todos sus ciudadanos son mestizos. De 1880 a 1920 la élite proyectaba imágenes de los indígenas como primitivos marginados que bloqueaban el progreso por su ignorancia y sus prácticas derrochadoras en sus propiedades comunales. A la vez, racionalizaban y reflejaban las políticas que llevaron a la expropiación de las tierras de los pueblos originarios del pacífico centro y norte del país, sumado a la cruda explotación del trabajo forzado y sin salario de las y los indígenas Matagalpa. Teniendo como resultado, el levantamiento indígena Matagalpa del 30 de marzo 1881 y la cruda represión estatal de parte del gobierno de Joaquín Zavala, al mando del General Miguel Vélez Morazán, quien casualmente se había destacado en la Batalla de San Jacinto, luchando con los 60 flecheros indígenas de Matagalpa y que a la postre, se convirtió en el principal verdugo en la ciudad de Matagalpa (Cruz, 2018).

Posteriormente, vemos que el Estado nicaragüense lanza tres concepciones diferentes de lo que era la nación, la patria y su discurso histórico, en su mayoría muchos de los contenidos y matices ideológicos, se encontraban cargados con sobredosis de fundamentalismo, colonialismo y un poco de hegemonía de dominación espiritual y socio cultural, mientras que en la parte económica se empezó a priorizar planes de negocios con los territorios de los pueblos originarios del pacifico centro y norte de Nicaragua, para dar apertura al mercantilismo, la extracción de oro en Matagalpa, sumado al monocultivo del café y la venta de tierras comunales a las familias europeas de origen alemán, inglés, danés y norteamericano que arribaron a los departamentos de Matagalpa y Jinotega, en oleadas migratorias, siendo estos los primordiales proyectos de nación durante los Treinta y Cinco años Conservador.

Durante la revolución liberal de José Santos Zelaya (1893-1909) su ministro de Educación, José Dolores Gámez, publicó los libros Catecismo de Historia Patria y Catecismo de Historia de Centroamérica por medio de los que se transmitió a toda una generación de nicaragüenses un doble sentimiento de nacionalidad. Los jóvenes de la época aprendieron que su patria o país era Nicaragua y su nación, Centroamérica (Fernández, 2008). El presidente Zelaya se interesó por crear un proyecto político y cultural de nación, utilizando el paradigma de la modernidad, asimismo, el cultivo del café demandó que el Estado estableciera las condiciones económicas, políticas y sociales para su expansión.

Dentro de este proyecto de modernización estatal, se emitió la Constitución de 1894 que proveyó un marco legal para establecer la separación entre la Iglesia y el Estado, el derecho de propiedad y seguridad individual, la educación laica y gratuita, la formación de un ejército moderno, mientras que, a los pueblos indígenas del pacífico centro y norte, se les continúo expropiando y se les obligó a crear Juntas Directivas Administrativas para cada comunidad originaria, sumado a que Zelaya logró la anexión de la reserva la Mosquitia, al mismo tiempo, se estableció el 05 de septiembre de 1908, la bandera de la República de Nicaragua, retomando los colores azul, blanco, azul de la desaparecida Federación Centroamericana. 
A partir del golpe de Estado, al presidente José Santos Zelaya, en 1909 y la intervención estadounidense de 1910 hasta 1933, obstaculizó el proceso de consolidación del Estado nicaragüense, sufriendo un revés político y convirtiendo al país centroamericano, en una colonia más del imperio norteamericano, cuyo principal interés geopolítico, era boicotear la construcción de un canal interoceánico y tutelar un Estado "fuerte" que garantizara la estabilidad de la región centroamericana. Con esa intención la potencia norteamericana creó en 1911 la Recaudación General de Aduanas, en 1912 estableció el Banco Nacional, en 1917 instituyó la Alta Comisión responsable del manejo del Presupuesto Nacional, para 1923 creó la Ley Dodds (que era una ley electoral) donde los marines estadounidenses contabilizaban, resguardaban y validaban las elecciones nacionales y municipales del país.

Mientras que el respeto por los símbolos patrios, se manifestó en 1918, con la declaratoria como himno nacional, los versos del poeta nicaragüense Salomón lbarra Mayorga, escrito en sol mayor, ejecutado en aquel momento en el país (La Gaceta, 30 de diciembre de 1918). Para década de 1922, ya se enarbolaba el pabellón, en las fiestas cívicas nacionales con veintiún cañonazos, siendo obligatorio para todos los ciudadanos de la República descubrirse y ponerse de pie cuando oyeran tocar el himno nacional, o cuando pasara el pabellón, en manos de un oficial del Ejército, en desfile; los militares armados presentarían su arma y los francos deberían cuadrarse (La Gaceta, 9 de agosto de 1922).

Según los autores citados, fue durante el periodo de ocupación que el Estado nicaragüense, comenzó a demostrar cierto interés en la transmisión de un sentimiento de pertenencia nacional, a través del fomento y del culto a los símbolos patrios. Sin embargo, no se dio a un nivel nacional debido a que durante la administración estadounidense jamás la educación fue prioridad para los invasores, como indican Rodríguez (2005) y Gobat, (2005). Mientras que, para el caso de las diversiones públicas, en vez de ser usadas para transmitir un sentimiento de pertenencia nacional, fueron utilizadas para conservar la situación de la ocupación militar norteamericana, aumentar la dependencia económica y política de Nicaragua con el imperialismo Yankee. La situación llegó a tal extremo que el periódico La Tribuna en 1925 señalaba que:

En Nicaragua por desgracia, tanto en el h ogar como en las escuelas y en todas partes, el culto a la patria no existe; $y$ de alli proviene que el sentimiento predominante entre los ciudadanos es el del primitivo egoismo, que solo inspira la idea de lucha y de sacrificio por la propia individualidad y por los propios intereses, pero que permanece indiferente ante los peligros y los sufrimientos del pro común. Además, indica que, en la lucha por la segunda independencia, nuestros mayores dieron pruebas de valor en los combates, de paciencia en la adversidad, de constancia en los reveses, de fortaleza en las privaciones, todo esto los ponía en un nivel muy superior al de sus descendientes, entre los cuales unos habian traido sobre la patria la esclavitud económica y política. Nicaragua estaba a merced del capitalismo extranjero, que continúa explotándola sin misericordia, y de los políticos profesionales de los partidos Liberal y Conservador que se disputan el predominio del poder para sacar las ventajas consiguientes a las ruinosas negociaciones con los explotadores de afuera" (La Tribuna, 13 de septiembre de 1925, p.2).

Para 1928 los EEUU, crearían la Guardia Nacional, alrededor de este marco institucional surgió y se desarrolló la dictadura genocida de la familia Somoza (1936-1979), durante todo el periodo de ocupación militar estadounidense, el "Estado nicaragüense" fue un protectorado manejado por las corporaciones extranjeras, los banqueros, la Iglesia y las clases políticas "vende patria" que utilizaba las instituciones públicas, para alimentar el sistema jurídico, ideado para favorecer a los ciudadanos de la potencia invasora y a la United Fruit Company, que básicamente controlaba la economía y la política de los países centroamericanos 
desde finales del siglo XIX, hasta la década de 1970, ya sea mediante el abuso de su poder económico, amenazas de violencia o sobornos a gobernantes, incluso preparó un golpe de Estado apoyado por la $\mathrm{CIA}$ contra el presidente guatemalteco Jacobo Árbenz (Selser, 1961).

Durante los años de la dictadura somocista, las únicas efemérides de trascendencia nacional promovidas por el Estado nicaragüense, durante los años de estudio eran la celebración de las fiestas de Independencia, la Batalla de San Jacinto y el 12 de octubre o "Día de la Raza" (Ayerdis, 2005). Asimismo, la gratuidad de la educación primaria estaba establecida desde la década de los ochenta del siglo XIX, esta medida no se observaba rigurosamente, hasta los años treinta del siglo XX, donde cerca de $70 \%$ de la población en edad escolar era analfabeta; porcentaje que se incrementó en las zonas rurales del pacífico, sur, centro, norte y caribe (Cumberland, 1978). En 1928 las denuncias en el diario La Tribuna, iban en aumento, justamente el 14 de septiembre el periódico resaltó que:

Nicaragua se encuentra sometida al mismo extranjero que fue impotente para subyugar a nuestros abuelos, que se juntaron, olvidando sus pasiones y sus rencores, para rechazar al filibustero; pero que ahora, encontrando degenerados a los descendientes de aquellos héroes, explota esa degeneración, los hace despedazarse unos a otros" (La Tribuna, 14 de septiembre de 1928, p.1).

En múltiples ocasiones, el mencionado periódico aclaró que en 1821 se rompieron las cadenas con España, pero que para 1928, las remachaba con inaudita crueldad una poderosa nación, que no habla nuestra lengua, menosprecia nuestra raza y no contempla a Dios, bajo el mismo prisma que las y los nicaragüenses lo hacían. Dicha potencia masacró, la última resistencia del Ejercito patriótico dirigido por el heroico doctor y General Benjamín Zeledón Rodríguez en la fortaleza de Coyotepe, arrastró su cadáver, como bandido por las calles de Masaya. Como resultado de la intervención estadounidense en Nicaragua de 1912, de esta manera, la sociedad fue experimentando un fuerte sentido nacionalista y principalmente antiimperialista, es decir, a raíz del sacrificio del ejército patriota atrincherada en Coyotepe, bastó para quedar completamente marcada toda una generación de nicaragüenses que, ante todo, entendieron, la importancia de defender la nación, defender su independencia, su soberanía política, económica y con ello garantizar la conservación y firmeza americana que nos caracteriza. En este sentido, en Nicaragua, la ocupación norteamericana impuso los pactos, acuerdos y los tratados políticos de nación, casualmente, después del acuerdo libero-conservador, conocido como "Pacto de Transacción" de 1924, en las elecciones inmediatas triunfó la fórmula conservadora republicana apoyada por el presidente Bartolomé Martínez, misma que estaba constituida por el conservador Carlos José Solórzano (presidente) y el liberal Juan Bautista Sacasa (vicepresidente), resultando derrotado el caudillo conservador Emiliano Chamorro.

Desde entonces Emiliano Chamorro, el 25 de octubre de 1925, impulsó acciones de desestabilización contra el gobierno constitucionalmente elegido en las elecciones de 1924, de Carlos Solórzano, mismo que culminó con el golpe de Estado, del 17 de enero de 1926, conocido históricamente como "El Lomazo". Sin embargo, el entonces gobierno de EEUU, no reconoció el golpe, porque violaba los acuerdos de Washington firmados por el propio caudillo Emiliano Chamorro en 1923. Asimismo, la Constitución ordenaba que, en caso de renuncia del presidente, quien debía asumir era el vicepresidente, que en todo caso le competía a Juan Bautista Sacasa, mismo a quien Emiliano Chamorro obligó a renunciar. 
No obstante, los norteamericanos no aceptaron ni a Sacasa ni a Chamorro, a través de las "notas Kellongg", la embajada Yankee presionó para que Emiliano Chamorro, renunciara al poder, ante la falta de reconocimiento internacional y nacional, Chamorro dejó el poder, pero en otro conservador, tras la breve presidencia de Sebastián Uriza, para que poco después, el ex presidente Adolfo Díaz ocupara la silla presidencial impuesto una vez más por los mismo estadounidenses.

El 14 de noviembre de 1926, Juan Bautista Sacasa se nombró presidente, alegando que la Constitución le daba el derecho, los bandos políticos criollos se volverían a enfrentar en otra guerra fraticida. En medio de esta situación, apareció Augusto Nicolas Calderón Sandino, quien procuró incorporarse al Ejército Liberal Constitucionalista, con un pequeño grupo de hombres, con quien se dirigió hasta Puerto Cabezas, donde ayudado por unas prostitutas, recogió del agua un buen lote de armas y municiones, que habían sido quitadas por los marines al ejército de Juan Bautista Sacasa, luego Sandino acudió a Prinzapolka, lugar donde se encontraba José María Moncada, general en jefe del Ejército Liberal del Caribe, sin embargo, este receloso de Sandino, le negó el uso de esas armas, aunque luego de un par de horas se las devolvió. Hecho esto, Sandino y sus hombres emprendió el viaje a la Segovia (su zona de operaciones) viajando en pipante por las aguas del río Coco.

\section{El Ejército Defensor de la Soberanía Nacional}

Sandino se alzó en armas el 26 de octubre de 1926, liderando a un grupo de mineros de la mina de San Albino y organizando a un grupo de hombres y mujeres que se oponían firmemente a la ocupación gringa en Nicaragua, el grupo de patriotas fundó al Ejército Defensor de la Soberanía Nacional (EDSN), y utilizó los colores rojo y negro, rubores bases que también fueron utilizados por los indígenas Matagalpa contra los españoles siglos atrás; el grupo de hombres también fue conocido como "Los Montañeses", quienes atacaron el cuartel conservador en El Jícaro el 2 de noviembre de 1926. En uno de sus manifiestos del 1 de julio de 1927 declaró

Soy nicaragüense y me siento orgulloso de que en mis venas circule, más que todo la sangre india, que por atavismo encierra el misterio de ser patriota, leal y sincero".

El primer paso de Sandino fue obtener armas, explosivos, organizar a los campesinos, a los indígenas de la Segovia, como a los Miskitu y Mayangnas de la región del rio Coco y Bocay, de esta manera "el ejército loco" encontró en la región centro y norte del país, las condiciones favorables geográficamente como sociales, para desarrollar su proyecto político militar, pues se encontraban en el óvido de las ciudades tradicionales y de la clase política dominante de aquel entonces (Cruz, 2018). El discurso del general Sandino, tuvo mucho eco en la población segoviana casualmente, porque la clase política liberal, fueron incapaces de darles un lugar como ciudadanos a los indígenas y campesinos.

Por el contrario, su ideología del progreso les hacía ver en ellos el principal obstáculo para el desarrollo del país. Desde esta óptica, podemos inferir que tuvieron una postura racista frente al indígena, según ellos, los oriundos no querían asimilar la cultura y los valores del progreso europeo. Resistencia que legitimaba el uso de la fuerza y la violencia contra los pueblos originarios con el fin de hacerlos ingresar en el camino de la "civilización" extractivista. El racismo contra el indígena, de parte de los liberales, se tradujo en una actitud de desprecio a las clases populares, en conjunto; de la población rural en general y, en particular de la población negra, robada de África por los europeos colonialistas siglos atrás, para trabajar en los enclaves bananeros y en las plantaciones de caña de América. 


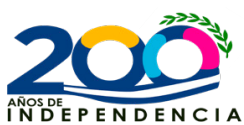

En resumidas cuentas, el liberalismo nicaragüense se quedó corto como proyecto de desarrollo político, precisamente porque se desentendió de la democracia y de la promoción de los derechos del individuo y de los pueblos subordinados. Al mismo tiempo, imitaban al máximo la cultura, la moda y los modos de vida anglosajón y norteamericano, mirando despectivamente la cultura popular campesina, negra e indígena, además, de la herencia colonial hispánica. Dentro de la lógica nacionalista y, a la vez, religiosa la lucha por echar de Nicaragua a los marines y dejar de ser colonia Gringa, se transformó en una cruzada redentora. El 2 de septiembre de 1927, centenares de indígenas y ladinos segovianos llegaron hasta el cuartel en el Chipote, a juramentase como soldado del Ejército Defensor de la Soberanía Nacional (EDSN).

En los momentos de mayor auge, entre 1931 y 1932 el EDSN llegó a tener alrededor de 2,000 combatientes, una reserva militar de unos 1,800 hombres y la base social entre las comunidades indígenas del centro norte de Nicaragua. El apoyo masivo de los indígenas y campesinos mestizos segoviano al ejército sandinista explica su capacidad de resistencia, pese a la descomunal superioridad militar de las fuerzas norteamericanas (Kinloch, 2009.pag.245).

El 3 de octubre de 1932, los candidatos a la presidencia Juan B. Sacasa y Adolfo Díaz, acordaron negociar la paz con Sandino después de las elecciones amañadas, donde triunfó Juan B. Sacasa, quien tomó la presidencia el 1 de enero de 1933, en ese momento los EE.UU. inició el retiro de sus tropas fuera de Nicaragua, siendo este la principal condición que exigió el general Augusto Sandino, para llegar al acuerdo de entregar las armas. Sin embargo, Somoza sabía que Sandino era un obstáculo para sus ambiciones de poder, y el 21 de febrero de 1934, aprovechando un viaje del exitoso líder guerrillero a Managua, fue traicionado y capturó cuando salía de cenar con el presidente Juan B. Sacasa, del Palacio presidencial, después, Sandino fue conducido hasta el aeropuerto y fusilado a sangre fría (Kinloch, 2009. pag,253). Con el asesinato del general Augusto Sandino, los estadounidenses vuelven a controlar los hilos políticos de Nicaragua, alimentando las aspiraciones de Somoza para obtener la presidencia con todo el apoyo de Washington.

\section{De la Dictadura a la Revolución}

La sustitución de los partidos políticos tradicionales por regímenes militares fue un fenómeno generalizado durante los años de la Gran Depresión, que estaba viviendo el sistema capitalista, quien se hallaba sumido en una gran depresión económica, luego de la quiebra de la bolsa de valores de Nueva York en 1929, donde la economía centroamericana se había visto sacudida por la caída del café.

La presencia norteamericana, directa o indirectamente, contribuyó a la estructuración del país, volviéndolo cada día más dependiente, a los intereses económicos y geopolíticos del imperialismo. En la parte económica, el país tuvo una diversificación de la estructura productiva y exportadora de algodón, ganadería, caña, tabaco; como respuesta a factores exógenos. Asimismo, hubo un auge de la economía internacional tras la finalización de la Segunda Guerra Mundial (1939-1945) y la guerra de Corea (19501953), la caída en el precio del café, aumentó el precio del algodón, desarrollando rápidamente las cadenas de comida rápida en EE.UU. 
Mientras en Nicaragua, el avance algodonero estimuló, los buenos precios internacionales e incorporó productores nuevos, no obstante, la dictadura somocista prohibió la siembra del algodón (dapan) ${ }^{1}$ nativo a los indígenas en las montañas de Matagalpa, precisamente en la comunidad de Sébaco y El Chile, donde se elaboraban trajes típicos con algodón nativo y utilizaban la técnica de cintura única en Centroamérica. La "modernización" de la agro exportación marginó a los pequeños y medianos productores, por su escasa dotación de recursos, e ingresos en un proceso de empobrecimiento y desposesión, sumado a la concentración de la tierra en manos de la oligarquía y burguesía vinculada a la familia Somoza.

Estos hechos, fueron antecedentes determinantes para la fase de 1956 a 1960 que coincide con el inicio de una crisis general del sistema, en el aspecto económico, político y social, desatando los movimientos sociales en el sector estudiantil, magisterial, obrero e indígenas, pero principalmente con el surgimiento de conspiraciones y movimientos armados, en diferentes lugares del país, como la guerrilla conservadora del 31 de mayo de 1959 en Olama, Boaco, Los Mollejones y Chontales. Luego nació, la guerrilla dirigida por Chale Haslam, en junio de 1959, en las montañas de Matagalpa, particularmente en la zona de Las Bayas, Pancasán y El Bijao.

Por otro lado, el 24 de junio de 1959, se desarrolló la guerrilla del frente revolucionario, en la zona conocida como El Chaparral, en el borde fronterizo con Honduras, en dicha masacre, calló en combate el veterano guerrillero sandinista general Ramón Raudales², pese a la derrota militar de El Chaparral, fue la mayor escuela militar de los jóvenes revolucionarios, quienes casualmente entraron en contacto generacional, con los viejos guerrilleros del extinto Ejercito Defensor de la Soberanía Nacional.

Posteriormente de los hechos, los líderes del frente revolucionario se trasladaron a la zona norte de Danlí, en Honduras de donde retornarían a Nicaragua, llegando hasta el valle de Teotecacinte, donde inició una incursión armada, con el objetivo de emboscar a la Guardia Nacional en El Dorado, donde el movimiento guerrillero logró dispersar a la genocida Guardia somocista y capturar al espía norteamericano Thomas D'cap, miembro de la contrainteligencia en la II Guerra Mundial.

A raíz de todos los antecedentes históricos, y de la misma ocupación norteamericana en Nicaragua, va a nacer el 23 de julio de 1961, el Frente Sandinista de Liberación Nacional (FSLN), organizado por el ideólogo y comandante en jefe Carlos Fonseca Amador, Noel Guerrero, Santos López ${ }^{3}$, Silvio Mayorga y Tomás Borge. Además, de José Benito Escobar, Jorge Navarro, Francisco Buitrago, Modesto Duarte, Rigoberto Cruz, Faustino Ruiz y Germán Pomares, quienes decidieron retomar la bandera del máximo héroe nicaragüense Augusto Sandino, y proseguir su inconclusa lucha de liberación nacional, hasta expulsar la injerencia estadounidense y sus lacayos de una vez por todas del país centroamericano, de acuerdo con Sergio Balardini dice que:

La década de los sesenta, idealizada por muchos... fue también, el tiempo de explosión y expansión de las subculturas juveniles: de los jóvenes entre el Che y la guerra fría. Una década que navega entre la radicalización politica y la contra cultura. Alternativos, iracundos, militares y radicales. La sociedad se moviliza y los jóvenes ocuparon la primera línea". (Balardini, 2000.pag.8)

Pese a la brutal represión de la Guardia Nacional, en 1972 los sandinistas habían logrado organizar, una base de apoyo en zonas rurales de las Segovia y a través del Frente Estudiantil Revolucionario (FER), se creó numerosas celulas urbanas en la región del pacífico, sobre todo en los círculos universitarios de todo el país. Según Kinloch (2009), sordo a las críticas, el dictador Somoza llevó a cabo otra farsa electoral apoyada por el gobierno de los EEUU, su lema de campaña desplegado en carteles y calcomanías, proclamaba en inglés "SOMOZA FOR EVER". 


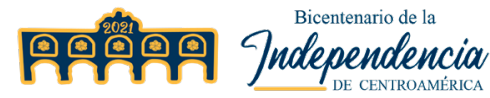

En septiembre de 1974, se auto proclamó triunfador con un amplio margen de votos, en dicha etapa el movimiento guerrillero, sufrió una división en tres tendencias políticas militares: insurreccional, proletaria y guerra popular prolongada, originadas por diferencias en las concepciones tácticas de la forma de enfrentar a la dictadura. Uno de los últimos pilares en sumarse a la lucha, contra la dinastía somocista en 1975, fue la misma Iglesia Católica, dirigida por el cardenal Miguel Obando y Bravo quien legitimó las acciones del FSLN. Así fue que, el movimiento guerrillero logró aglutinar todos los sectores descontentos revolucionarios, liberales y conservadores, e incluso ganarse a la opinión pública internacional para acabar, por fin, con la tiranía somocista y la ocupación norteamericana.

Durante los últimos meses del año 1975, la juventud entra en un proceso de cambio drástico, pasando al olvido las modas, la vanidad y pasan a jugar un papel fundamental en contra de la lucha y el boicot a la dictadura. Mientras la genocida Guardia Nacional somocista, continuó reprimiendo y asesinando a los campesinos, indígenas y obreros en las regiones urbanas y rurales del país, para un 8 de noviembre de 1976, los esbirros del pueblo, lograron atrapar al líder e ideólogo revolucionario, fundador del Frente Sandinista de Liberación Nacional Carlos Fonseca Amador, quien fue ejecutado por ordénes claras de Somoza. La tensión política aumentó, mientras el régimen se hallaba bajo constante ataque desde el diario La Prensa, que denunciaba sin miedo las violaciones a los derechos humanos, las masacres y la infame corrupción del gobierno somocista. Un 10 de enero de 1978, su director Pedro Joaquín Chamorro fue acribillado por matones somocistas.

Para el 22 de agosto de 1978, el movimiento guerrillero demostró la vulnerabilidad de la dictadura somocista, con la operación "Chanchera", cuando veinte y cinco jóvenes guerrilleros asaltan "El Palacio Nacional de Nicaragua", penetrando así en las estructuras somocistas y obligando a la dictadura liberar a los principales líderes del movimiento guerrillero nicaragüense. Tres días después, la ciudad de Matagalpa protagonizó la "Insurrección de los Muchachos" logrando frenar durante cinco días la represión dantesca de los verdugos del pueblo en toda la ciudad de Matagalpa, hasta la siguiente semana que entró los refuerzos de la EEBI, a sofocar la primera insurrección del país.

Los siguientes meses del año la crisis se profundizaba cada vez más, el miedo se había perdido, la lucha seguía, en todas las ciudades del país, no habia otra alternativa que pelear con las armas, para deponer a un gobierno genocida y dejar de ser colonia norteamericana, en dicho contexto los nicaragüenses se sumaban a los frentes de lucha, en los diferentes puntos clave, para entrar a la etapa final de la crisis del sistema somocista y capitalista en Nicaragua. Sin embargo, la Guardia Nacional siguió ejecutando acciones criminales contra su propio pueblo, la represión y bombardeo a las ciudades más importantes no se hicieron esperar, en dichas acciones murieron miles de civiles, mientras tanto los jóvenes se unían voluntariamente a los movimientos guerrilleros en las ciudades y en las montañas" (Cruz,2019).

Para el año de 1979, las tres tendencias revolucionarias firmaron la unidad sandinista y llamaron a todo el pueblo a la lucha frontal contra la dictadura somocista, tanto en la huelga general como en las actividades insurreccionales, desencadenando la ofensiva final en todos los frentes de guerra organizados en el país, contra las posiciones de la Guardia Nacional. De esta manera fue, que el pueblo nicaragüense conquistó su segunda independencia, no sólo de la tiranía familiar somocista, sino también de su verdugo tradicional "El Tío San", quien desde 1912 hasta 1979, gobernó el país bajo sus intereses geopolíticos y corporativos de clase.

\footnotetext{
Árbol de Algodón=Man dapan múkare. Según don Hipólito Líder indígena de la cañada del Chile, popularmente se llamaba Algodón de páis, el cual tiene 1 metro de altura y el que hay ahora el árbol de algodón de Panilla.

${ }^{02}$ Decidió en 1958 reiniciar la lucha armada contra el régimen somocista, por lo que organizó dos columnas de 40 hombres que penetraron a Nueva Segovia por Teotecacinte el 15 de septiembre. El 14 de octubre, la columna del General Raudales sostuvo un combate de más de siete horas contra una compañía de 120 guardias, en estas acciones el General Raudales fue herido y cuatro días después murió.

${ }^{03}$ Veterano guerrillero Sandinista, perteneciente al coro de Ángeles del EDSN.
} 


\section{De la segunda Independencia a la Guerra Contrarrevolucionaria}

La Revolución Popular Sandinista, empezó el 19 de julio de 1979, fecha histórica celebrada por cientos de miles de nicaragüenses, unificados bajo los principios sandinistas, de "Patria Libre o Morir", principios sociales y políticos heredados por la gesta del general Augusto Nicolás Calderón Sandino. La naciente revolución tuvo como principal proyecto, luchar contra el analfabetismo, anular los tratados que lesionaban la soberanía nacional, por ello, se desconoció el "Chamorro-Bryan", se trabajó para crear el Ejercito Popular Sandinista, La Policía Sandinista, el Ministerio del Interior, el Ministerio de Cultura y el Instituto Nicaragüense de Reforma Agraria quien trabajó en democratizar el acceso a la tierra y confiscar las propiedades de las familias burguesas y oligarcas afines de la dictadura militar somocista.

Las primeras medidas tuvieron como objetivos erradicar el analfabetismo en toda Nicaragua, la segunda tuvo un sentido geopolítico al desconocer un tratado político con los EEUU, que le prohibió al país la construcción de un canal interoceánico en un periodo de 100 años y la tercera medida estaba orientada a los grandes terratenientes vinculados a la familia Somoza, quienes controlaban una quinta parte de las tierras cultivables principalmente en la zona (Close, 2005, p. 44).

Particularmente, estas fueron las bases del reparto agrario sandinista para la organización estatal de la producción y la reorganización de las actividades económicas, a través de las cooperativas campesinas, las cuales en su mayoría se encontraban en los territorios de las comunidades indígenas del pacífico, centro y norte. La implementación de la reforma agraria durante el periodo revolucionario amplió el acceso a la tierra a los campesinos e indígenas empobrecidos en todos los departamentos del país.

Con la implementación de las innovaciones agrarias, la revolución sandinista en los primeros años mejoró el sistema de crédito y democratizó la distribución de tierras. Sin embargo, para 1981 se formó en la zona fronteriza con Honduras la agrupación de mercenarios y exguardias somocistas denominados "Los Milpas" con 600 hombres que rechazaban la victoria popular de las milicias sandinistas. Estos paramilitares armados, contaron con el apoyo logístico y financiero de la agencia de inteligencia CIA, de los EEUU, quienes desde territorio hondureño venían realizando trabajos subversivos, hasta el nacimiento del "Frente Democrático Nicaragüense"y luego llegar a fundar a la Contrarrevolución la que para 1986, llegó a tener 17,032 soldados, y en 1987, un año después de la reforma agraria ya sumaban 17,500 hombres en armas (Morales, 1989; Núñez y Cardenal, 1992).

Así fue que Ronal Reagan, utilizó el discurso del anti comunismo centroamericano, para levantar un embargo comercial, contra la naciente revolución sandinista, por si fuera poco, la CIA ideó un plan de abastecimiento, asesoría y alimentación a los mercenarios, además, dicha planificación comprendió el tráfico ilícito de más de 16, 000 toneladas de cocaína rumbo a los EEUU, que servirían para mantener la logística y la guerra en Nicaragua (Cruz, 2019). Siendo los más de 9 años de guerra en la década de los $80^{\prime}$, una nueva agresión del imperialismo norteamericano, contra el pueblo nicaragüense, teniendo como único objetivo destruir y sofocar la segunda independencia del pueblo de Nicaragua, con el claro propósito de desgatar a la población civil, al recién creado ejército y policía nacional, además, de desmoralizar a las milicias revolucionarias y lograr así aniquilar la naciente revolución popular sandinista. 
El gobierno nicaragüense, en medio de la desgastante guerra y bloqueo instauró una serie de políticas de comercialización y distribución de los productos agrícolas, regulando los precios de los granos, para tener control de las semillas básicas que se producía en el país, a través de la Empresa Nacional de Alimentos Básicos (ENABAS). Las medidas fueron tomadas bajo un contexto de guerra impuesta que de cierta manera, atentaba contra los comerciantes e intermediarios acostumbrados a especular con el valor agregado de los productos agrícolas. La guerra poco a poco iba desgastando la frágil economía agroexportadora de Nicaragua y golpeando contundentemente a los civiles por el racionamiento de los alimentos, escases de utensilios personales, como pasta, máquinas de afeitar y otros productos importados, mientras se racionaba el arroz, aceite y azúcar (Cruz, 2019).

Entre 1987 y 1988 el gobierno revolucionario implementó el Plan de Ajuste que residió en una reforma monetaria, que consistía en devaluar el córdoba respecto al dólar en una relación del 80 a 1, esta difícil situación aumento el descontento de un amplio sector de la población campesina y urbana, quienes históricamente han tenido dependencia y seguridad en la primera moneda de intercambio internacional. Pero no doblegaba a los sandinistas revolucionarios, que mantuvieron un gobierno bajo un embargo económico, carencias de productos y una alta inflación de una economía de guerra. Las medidas del Plan Ajuste consistieron en ajuste salarial, centralismo político, reestructuración económica y crediticio, renegociación de las deudas bancarías, la liberalización de los precios y salarios, reducción en el presupuesto de salud y educación. Para 1989 el empleo público disminuyó, afectando a 50, 000 mil personas, mientras la tasa de desempleo rondaba el $28 \%$ (Vilas, 1993).

Las carencias y dificultades de los nicaragüenses se sentían en las necesidades básicas de subsistencia, tras décadas de dependencia comercial con los EEUU, quien termina imponiendo un embargo económico desde 1983 y una guerra al país, que le costó más de 50, 000 vidas humanas y más de 16, 000 víctimas de guerra de ambos bandos.

Para las elecciones de 1990 la crisis económica y política en el país era muy profunda a causa de la imposición bélica, con la victoria electoral de Violeta Barrios de Chamorro, los movilizados campesinos de la Contra se lanzarían sobre los territorios de las comunidades indígenas desalojadas por el conflicto armado; de esta manera muchas familias campesinas, se asentaron en las antiguas aldeas indígenas en las riveras del rio Coco, Bocay, Ayapal y Runflin. Asimismo, el denominado campesino de la frontera agrícola es un sujeto social con una identidad cultural propia, enriquecida con el mito dominante del Estado Nación, que se impone a las otras formas de organización social y cultural de la tierra, es decir, se opone a los derechos de las poblaciones autóctonas de BOSAWAS y las regiones autónomas del Caribe norte y sur. Justamente, porque el colono de la frontera agrícola se siente heredero de la ideología del Estado nación, abrazando las políticas expansionistas y extractivistas de la modernidad hegemónica y el comercio de madera, pieles, oro y plantas medicinales, asimismo, cabe resaltar que las comunidades Miskitu y Mayangnas del rio Bocay, rio Coco y caribe Norte de país, siguen sufriendo los ataques perpetrados por colonos contra los pueblos originarios, particularmente en la región de KiwaKumbaih, territorio de Musawas, también, en la región del Idian Miskitu Tasbaikam Kum, Mayagna Sauni Bu y en regiones de a Alamikamba. 


\section{Del Neoliberalismo al retorno del Sandismo}

El 25 de febrero de 1990, se efectuaron las elecciones generales dando como resultado la victoria electoral de Unión Nacional Opositora con el $54 \%$ de lo votos, mientras el FSLN tuvo el $40 \%$ de los votos. Lo primero que hizo el gobierno de la presidente Violeta Barrios de Chamorro, fue anunciar una propuesta de ley relativa a la revisión de las confiscaciones sandinistas, buscando como beneficiar a todas las familias vinculadas a la dictadura somocista y aceptores burgueses que se vieron afectados durante el gobierno revolucionario. En los hechos se trató de la primera contra reforma agraria de corte netamente neoliberal que se desarrolló en el país, otra transformación fue la libertad comercial para los campesinos y productores para que ellos decidieron a quien venderle sus productos, al mismo tiempo, se privatizaron todas las empresas del Estado heredadas del gobierno revolucionario (INCEP, 1994).

Al mismo tiempo, eliminó las políticas de control estatal y de carácter distributivo e impone el libre mercado, en un sentido neoliberal globalizado, lo que incluía las empresas nacionales y los intentos por destruir el sandinismo desde todos los focos y campos ideológico, esto provoco una división entre los dirigentes y comandantes de la revolución, quienes muchos optaron por formar el Movimiento Renovador Sandinista (MRS) hasta instaurar una democracia desigual netamente procedimental y electoral. Asimismo, el "Tío Sam" como muestra de la simpatía política, al gobierno de transición de la señora Violeta Barrios de Chamorro, no dudo en aprobar inmediatamente un paquete de ayuda económica de $300 \$$ millones de dólares, mismos que fueron condicionados por los norteamericanos, al momento de realizar el desembolso fue de 147\$ millones, esta acción complicó más al gobierno neoliberal, pues era en los meses donde más se necesitaban fondos para la reducción del Ejército Popular Sandinista (EPS) y al Ministerio del Interior (MINT) al que se le obligó a retirar a una buena parte de sus miembros, por el otro lado, se desmovilizando a 22, 413 combatientes de la Contrarrevolución (UNO,1990 p.8).

Por otro lado, los EEUU impuso a la Comisión Internacional de Apoyo y Verificación de la Organización de Estados Americanos (CIAV-OEA) quien debía de administrar los 300 millones de dólares, otorgados en carácter de préstamos de los cuales, sólo el $10 \%$ se destinó a la desmovilización de los Contras y los restantes $90 \%$ fueron destinado al gobierno neoliberal de Violeta Barrios de Chamorro. Para 1990, existían 60, 000 demandantes de tierras y más 2,000, 000 millones de familias campesinas e indígenas afectadas por el problema de la propiedad, además, de más de 6,000 mil ex propietarios, que exigían la devolución de las tierras confiscadas por la revolución sandinista. Así fue que el gobierno neoliberal vendió las Corporaciones Nacionales del Sector Publico (CORNAP), como un mecanismo de privatización y devolución del patrimonio del Área de Propiedad del Pueblo (APP), que representaba para 1990 aproximadamente el $40 \%$ del producto Interno Bruto (PIB) de Nicaragua, y empleó a más de 78, 000 trabajadores, sin embargo, el gobierno neoliberal no le interesaba el pueblo empobrecido y no tardo en desmembrar y privatizar las tierras a beneficios de los mismos grupos de poder históricamente excluyentes del país (Rueda, 2019).

Para rematar al pueblo, el gobierno de Violeta Barrios, condonó de manera ilegal la deuda de 16, 000,000 millones de dólares que el Tribunal Internacional de Justicia (TIJ), de la Haya en Holanda falló a favor de Nicaragua, responsabilizando a los EEUU, de violar el derecho internacional al apoyar a la oposición armada y ser el principal promotor de la guerra en el país. Sin embargo, con la condonación ilícita de la deuda histórica, las clases políticas tradicionales de familias liberales y conservadoras, oligarcas y burgueses se repartieron jugosos prestamos económicos y rápidamente se volvieron a enriquecer a merced de las inmensas mayorías de nicaragüenses empobrecidas en el campo y las ciudades. 
De esta manera, la legislación nicaragüense aprobaría la inversión extranjera instaurando las maquilas y las zonas francas, donde la explotación capitalista se intensificó, sin embargo, la necesidad del pueblo forzó a miles de mujeres y madres solteras a buscar empleos con salarios fijos. Con la implementación del neoliberalismo nunca se llegó a cumplir las promesas electorales que llevaron al poder político a Violeta Barrios de Chamorro, pues la recuperación económica de Nicaragua nunca llegó y a partir de 1990 a 1992 la combinación criminal del desempleo, subempleo, ignorancia y pobreza extrema cubrió a más de dos tercios de la población económicamente activa en el país (Vilas, 1994, p.260).

Con la misma obediencia y entreguismo político, de inicios del siglo XX, los gobiernos libero-conservadores del Dr. Arnoldo Alemán (1996-2001) y el Ing. Enrique Bolaños (2002-2006), administrarían Nicaragua en medio de las adversidades económicas y sociales en una sociedad que venía de derrocar una de las dictaduras familiares más sangrientas y genocidas de Latinoamérica apoyadas por Washington, sumándole una guerra contrarrevolucionaria de más de nueve años apoyada y financiada por el mismo imperio norteamericano. Así fue, que la clase política tradicional, empujarían a millones de obreros, campesinos e indígenas a la miseria y pobreza extrema, sin mencionar los miles de personas lisiadas y víctimas de guerra, que nunca fueron atendidos por el gobierno y menos que tuvieran los beneficios de la supuesta ayuda "humanitaria" estadounidense que tampoco llegó a los campesinos e indígenas de la Contrarrevolución.

Siendo los gobiernos neoliberales de Violeta Barrios de Chamorro, Arnoldo Alemán y Enrique Bolaños, los más corruptos en todos los espacios sociales, favoreciendo a las minorías ricas del país, mientras trastocaban la vida de los campesinos e indígenas empobrecidos, durante los 16 años de neoliberalismo salvaje. La vida agrícola dejo de ser rentable y la migración a las principales ciudades del norte del país iban en incremento, según un estudio elaborado por la CEPAL (2007), muestra que los principales rubros de producción como son maíz y frijol no se habían mejorado en los últimos 40 años, pese a que se trataba de uno de los principales cultivos para la dieta local y son los cultivos que más área de siembra posee (Vivas, 2007, p.35). Así fue que entre los años 2001 y 2005, la población campesina e indígena rural empezó a migrar de una manera acelerada a las urbes como León, Managua, Estelí. Juigalpa y Matagalpa, donde la cantidad de indigentes y niños pidiendo un Córdoba iban en aumento estrepitosamente, es decir, la migración había sido menos durante los años de los rearmados que durante los años "pacíficos" o Republicanos como afirma el maestro Alejandro Serrano Caldera.

Con el retorno del FSLN al poder en Nicaragua, en el 2007 el país se encontraba en una de las crisis energéticas más grave de la historia republicana, sumado a la profunda crisis de los campesinos e indígenas de Chinandega víctimas del Nemagón. Además, de las familias campesinas e indígenas de Matagalpa y Jinotega que se encontraban sumidos en la miseria, los rearmados, la pobreza extrema, la desigualdad de género, la privatización de la salud, educación, la empresa de construcción y la cementera, entre otros males del neoliberalismo hegemónico. La expansión de la ganadería y la agricultura no había mejorado las condiciones del campesino y de los indígenas durante la posguerra, en el año 2008, la Organización de las Naciones Unidas para la Agricultura y Alimentación (FAO), el Fondo Monetario Mundial (FMI) y el Banco Mundial (BM), insistieron en que la solución a la crisis de alimentos estaba en impulsar la agricultura familiar (Bartra, 2006) 
Una vez asumida la presidencia Daniel Ortega Saavedra, desde el primer día, declaró que la salud y la educación serían completamente gratuitas en todo el país, asimismo, afirmó que estos dos sectores sería la prioridad durante su mandato, para el año 2008, creó los Gobiernos Territoriales Indígenas (GTI) del alto y bajo Wangki, reivindicando un derecho histórico alcanzado para la Nación Mayangna y Miskitu del rio Coco y Bocay, al mismo tiempo, creó la Secretaría de Asuntos Étnicos, en la Asamblea Nacional Nicaragüense, permitiéndole a los 22 pueblos originarios y a las regiones autónomas incidir en las políticas nacionales y regionales para los pueblos y comunidades originarias.

En el plano latinoamericano, Nicaragua con el apoyo de Venezuela logró superar la mayor crisis energética en la historia del país, asimismo, con fondos de la Alianza Bolivariana para los Pueblos de América (ALBA), realizó una serie de programas como Hambre Cero y Usura Cero, que fueron dirigidos a los campesinos de la frontera agrícola y los indígenas de Matagalpa y Jinotega, los programas tenían la finalidad de promover la producción alimentaria, robustecer la seguridad alimentaria de las familias y el acceso a créditos. El éxito de los programas implementados por el gobierno sandinista es innegable, también la reivindicación femenina, las trasformaciones al seguro social (INSS), las pensiones reducidas, a miles de familias que no lograron cotizar las 360 semanas.

Otro logro del sandinismo, es la disminución morbimortalidad materna, infantil de niños de 0 a 5 años, creó 178 casas maternas para las mujeres indígenas y campesinas. También, construyó 18 hospitales primarios a nivel nacional, la remodelación de los hospitales de mayor data, la inclusión del plan para adultos mayores, la integración a la sociedad de los pacientes con VIH/SIDA positivo, el plan de vacunación gratuito. Otro logro fue, la mitigación de la mortandad infantil de 0 a 5 años, la disminución de la desnutrición en niños de 0 a 5 años, las implementaciones de distintas normas para los diferentes sectores de la salud.

La fusión de la medicina natural con la medicina occidental, la implementación de las clínicas móviles, la implementación de los Hospitales Escuelas, en todo el territorio nacional ha sido, otro de los logros más importantes del gobierno del presidente Daniel Ortega Saavedra. También, el acceso a las universidades públicas, en el campo como en la ciudad incrementaron el número de becas a millones de bachilleres que no tenían oportunidad de estudiar en los departamentos de Managua, Estelí, Matagalpa, Carazo, Jinotega, Nueva Segovia, Bluefields o Puerto Cabezas; con ello se incrementó mayormente las plazas de trabajo, gracias al $6 \%$ constitucional, que durante 16 años fue una lucha de todos los días ante los gobiernos neoliberales. Los logros del gobierno son innegables, y contados sus desaciertos, sin embargo, la tenacidad del trabajo, la cohesión social del partido y el coraje de lucha por sacar de la pobreza, a miles de ciudadanos nicaragüense que, con la firmeza, mística, coraje y con el compromiso social a la patria decidió desarrollar este país empobrecido.

De esta manera, la inversión en el sector turismo fue uno de los logros más importantes del gobierno revolucionario, con ello la reducción de la pobreza extrema y pobreza se lograron reducir gradualmente de un $48 \%$ aún $20 \%$. Al mismo tiempo, el gobierno garantizó la alianza de consenso entre el sector público y privado desde donde se negociaba el salario mínimo y las trasformaciones al seguro social, al que los gobiernos neoliberales habían dejado en banca rota. Desde entonces, el gobierno sandinista ha venido luchando por transformar Nicaragua, en uno de los países más seguro del mundo, donde las mujeres tienen igualdad de oportunidades que los hombres y los inversionistas extranjeros puedan trabajar en un ambiente seguro y competitivo. Entre el 2010 al 2018 fueron años donde se empezaron a construir varios Hoteles tipo resort principalmente en el departamento de Rivas, estos negocios incluyen campos de golf, extensas playas, clubes hípicos y demás infraestructura que evidentemente se nutre de grandes extensiones de tierra. 
En las zonas turísticas, abundaban los empresarios internacionales y nacionales como el millonario Carlos Pellas "el hombre más rico del país", quien, además de invertir en el Ron Flor de Caña, importa vehículos japoneses, dueño de Bancos y ha incursionado con el complejo turístico llamado "Gucalito de la Isla", el que tiene una extensión de 6.5 kilómetros cuadrados.

El gobierno del comandante Daniel Ortega, continuó con las políticas extractivita de los presidentes antecesores, con la combinación exitosa de los programas sociales que han dado excelentes resultados a los campesinos e indígenas de la frontera agrícola, para el año 2012 el mismo FMl, le sugería al gobierno que modificara los años de jubilación y que cortara los subsidios a las universidades, a lo que la Unan Managua, salió a las calles a protestar no contra el gobierno, sino contra el FMI y sus paquetazos neoliberales, sin embargo, la política de conceso entre los afectados logro tener resultados exitosos, a tal punto que la deuda con el organismo internacional llego a cero (AFP,2016).

Otra muestra de las excelentes relaciones del gobierno sandinista con el capital trasnacional es la Inversión Extranjera Directa (IED), se va incrementando constantemente entre enero del 2005 y 2009, el crecimiento nacional fue 394 millones de dólares, en el 2011, iniciando el segundo mandato del Daniel Ortega, fue de 936 y en el 2012 alcanzó los 768 millones de dólares. Para el 2013 sumaba 816 millones de dólares, en el 2014 eran 884 millones de dólares de ingresos de la Inversión Extranjera Directa, sin embargo, el pico más alto fue para el año 2015 cuando alcanzó 950 millones, pero en el año 2016 y 2017 se registraría una caída del -2 en relación a los años anteriores al obtener 897 millones de dólares (CEPAL, 2018, p.30). Siendo sustantiva la inversión extranjera para el desarrollo del país, así fue que el gobierno sandinista seducido ante la inversión externa, aprobó la ley Canalera en Nicaragua, a partir del 2013 el inversionista Wang Jin cuenta con un plazo de 16 años para buscar el total del financiamiento para la construcción del sueño nicaragüense y los mega proyectos que lo acompañan. Los resultados de la ley 800 y 840 se dividen básicamente en dos, por un lado, los que están apoyando la mega obra y por el otro, los detractores de la misma (Gerrt, 2014).

Así fue que una parte de la oposición y de los "vende patrias" de Nicaragua encabezada por la señora Violeta Granero y otros líderes viajaron a Miami, para solicitarle a la congresista Marcos Rubio y lleana Rosse de los EEUU, sanciones contra personas particulares y sanciones contra el Estado nicaragüense, la propuesta es conocida desde Norteamérica como NICA ACCT, la cual estuvo en el seno del Congreso estadounidense y fue aprobada con unanimidad en dicho parlamento. También, solicitó que funcionarios del gobierno sandinista fueron incluidos en la ley extraterritorial, conocida como Magnitsky, que permite al gobierno de Washington, imponer dictatorialmente sanciones económicas unilaterales a ciudadanos de todo el mundo, que hubieran cometidos abusos a los derechos humanos y actos de corrupción en sus países de origen.

Asimismo, la supuesta oposición democrática desde el año 2010, estaba siendo financiada por la USAID, de acuerdo a los informes se dice que desde el año 2010, hasta el año 2020, la Agencia de los Estados Unidos para el Desarrollo Internacional, transfirió a los partidos políticos y organizaciones anti sandinistas, la suma de 68 millones de dólares, con el objetivo de desacreditar al gobierno nicaragüense, en el interior como en el exterior, cuando empezó la crisis política de abril del 2018, añadieron 8 millones de dólares a los medios de comunicación hegemónicos, por ese motivo, el incendio en la reserva Nutual Indio Maíz, fue mediatizado por los medios de comunicación al servicio del imperialismo y por una ONG's apoyada, por los intereses de los medios de comunicación de la oposición, rápidamente desprestigiaría las acciones del gobierno sandinista para control el voraz incendio que calcinaría apenas el $3 \%$ de la reserva de biosfera. 
Posteriormente, el gobierno sandinista publicó las trasformaciones al Instituto Nicaragüense de Seguridad Social (INSS), un tema del que tenían meses de discusión con la empresa privada, el FMl y el gobierno central, mientras como todos sabemos el FMI, aconsejaba incrementar la fecha de jubilación, y los sandinistas proponían expandir la cobertura del seguro a más trabajadores, en cambio la empresa privada decía que era insostenible la propuesta todo con tal de no pagarle los derechos que por ley, tiene las y los trabajadores. Una vez, que los medios de comunicación masivos crearon el estado opinión, con ellos vino la desinformación y la manipulación, de esta forma, fue que la comunicación fue sustantivo durante los siguientes meses, porque las redes sociales sirvieron de plataforma y los grupos de WhatsApp, fungieron como las herramientas de la desacreditación institucional. El plan de desinformación y "fakenews" fue la estrategia que utilizaron las organizaciones opositoras y la embajada estadounidense para dar inicio a la guerra mediática de cuarta generación, así fue que en un canal de noticias el señor Miguel Mora (2018) afirmó que:

El 18 de abril del 2018 se había asesinado a un estudiante de la UCA, quien fue víctima de la represión del gobierno Orteguista"

Sin presentar ni una sola prueba, del supuesto estudiante asesinado en la UCA, el 19 de abril del 2018, los medios de comunicación crearon la "fakenews" en las redes sociales, Facebook, WhatsApp y Messenger, la construcción de la opinión pública contra el gobierno sandinistas estaba hecha y servida, desde ese momento crearon las frases "nos están matando" y luego vinieron los hashtag de \#SOSNicaragua todo en referente a las reformas del INSS, y los supuestos muertos que la dictadura sandinista escondía. A los tres días el gobierno de Daniel Ortega, decidió derogar las Reformas al Instituto Nicaragüense de Seguro Social, no obstante, empezaron los asesinatos en las calles de jóvenes, entre ellos Álvaro Conrado quien andaba repartiendo agua cerca de las instalaciones de la UNI, y fue herido de gravedad durante las protestas aparentemente por un francotirador, mientras los estudiantes y La Prensa escrita, afirmaba a nivel nacional e internacional, sin haber realizado una investigación previa que eran personas armadas afines al gobierno, uno de los testimonios más claro es del opositor Alberto Luna (2018) quien afirmó que:

La protesta nuestra empezó con el incendio a Indio Maiz, después pasamos a las reformas al INSS, luego fue por los asesinatos del gobierno Orteguista"

La campaña de los medios de comunicación contra el gobierno estaba montada, de ahí se levantaron la sociedad civil, disfrazada de MRS, y continuaron las marchas y el gobierno sandinista empezó a realizar contra marchas, de esa manera fue que las calles se calentaron en todo el país. Posteriormente, se pasó de protestar en las calles a empezar a formar tranques en sectores de Tipitapa, Managua, Carazo, Masaya, Chontales, Rio San Juan, Rivas, Matagalpa, Esteli, Sabaco, Jinotega, Rio Blanco, Matiguás, Muy muy, Pantasma, Wiwili, Bocay y El Cua. En medio de la crisis, se realizó el primer diálogo Nacional, mismo que fue utilizado como "show mediático" contra el presidente comandante Daniel Ortega, al mismo tiempo, el joven Lester Alemán, mal asesorado le gritó al mandatario, exigiéndole su renuncia, pese a la difícil situación política y social, el presidente de la republica ordenó a las fuerzas de la Policía Nacional, acuartelarse en todo el país y al Ejercito le prohibió salir a las calles. 


\section{울ำㅇำ 9 malependencia}

Una vez acuartelada la Policía Nacional, los vagos e insurgentes controlaron las calles de las principales ciudades del país, así empezó el terror nunca antes visto en Nicaragua, mientras la oposición afirmaba que todos los muertos los había matado el "gobierno dictatorial" y las ONG's como ANPDH, inventaban cifras a alarmantes en los principales medios opositores al sandinismo a nivel nacional e internacional. Con ello cada día, que pasaba la inseguridad, los grupos delincuenciales y el descontrol social reinaba en las calles de las principales ciudades del país. Según un protagonista de los tranques en Matagalpa Hamilton Montenegro (2018) dice que:

Estuve en el tranqué de la calle ocho en Matagalpa, donde nos pagaban 500, 400, 200, 100 pesos por estar ahi, recuerdo que hasta la comida nos la llevaba una concejal por el CXL, PLC y ONG's quienes estaban dirigiendo los tranques con otras personas disidentes del FSLN, también, nos conseguian la marihuana, cocaína y hasta el crak, todo para que nos mantuviéramos bien fundidos en los tranques, sin hacer nada, o intimidando a los sapos sandinistas, asi pasamos casi tres meses".

Como resultado de los tres meses, de acuartelamiento a la Policía Nacional, se llegó a tener un saldo de 198 personas fallecidas, víctimas del terrorismo durante el periodo del 19 de abril al 25 de julio, entre ellos 192 hombres y 7 mujeres. También, según los datos de la Policía Nacional, 253 personas fueron fallecidas por muertes homicidas, entre los que tenemos 233 varones y 20 mujeres, que según la fuente perdieron la vida por actividades delictivas comunes y 2 mujeres fueron violadas en los tranques. Mientras el gobierno de Nicaragua y la empresa privada, cuantifica más de 1000 millones de dólares en pérdidas económicas, dejando a más de 300 presos políticos o políticos presos, en el sistema penitenciario, sin embargo, el presidente Daniel Ortega, decidió en agosto del 2018, aprobar una ley de amnistía que favoreciera a todos los detenidos durante el intento de golpe blando. De esta manera, el país siguió recuperando la normalidad política, sin embargo, la crisis económica del 2018 fue latente, incluso un año después de las protestas y como siempre las clases sociales afectadas, son la clase media y baja, mientras los empresarios del COSEP, siguen divididos y la Iglesia Católica haciendo proselitismo político contra el gobierno sandinista sin que hasta ahora tengan éxito.

Al mismo tiempo, el sandinismo desde la victoria contra el golpismo nicaragüense en junio del 2018 , hasta septiembre del 2021, se ve más fuerte que nunca y con sus militantes y simpatizantes, más activos que nunca desde las plataformas de opinión pública y redes sociales. Para tener una idea más coherente de todo el panorama, tenemos que desde el año 2010 al año 2020, la USAID, transfirió a los partidos político de derecha y organizaciones no gubernamentales, la suma de 68 millones de dólares, con el objetivo claro de desacreditar al gobierno sandinista, tanto en el interior como en el exterior, cuando ocurrieron las protestas en Nicaragua en el año 2018, la USAID añadió 8 millones de dólares, por lo que la contribución total de esa organización norteamericana, a la desestabilización del país, fue de 76 millones de dólares.

De esta manera fue, que los opositores perdieron otra vez, el horizonte de independencia y de Estado nación soberano, por ello, no se atreven a reconocer o resaltar los logros económicos y sociales del país centroamericano; $y$ es que hay que repetirlo hasta el cansancio, el sandinismo ha representado uno de los mayores logros económicos y sociales en Nicaragua, a pesar de todas las acciones desestabilizadoras lanzadas desde el imperio norteamericano. Casualmente, antes de la crisis del año 2018, el crecimiento económico en Nicaragua promedió $4.6 \%$ al año, beneficiándose de una sólida gestión macroeconómica y una serie de reformas destinadas a transformar el país en una economía de mercado. 
Sin embargo, a raíz del intento de golpe de Estado al comandante Daniel Ortega, la economía nicaragüense experimentó desde abril de 2018, un rotundo freno de la expansión económica y resultó una contracción económica de 4.0 y $3.9 \%$ en 2018 y 2019, respectivamente. Sumado a la pandemia del coronavirus covid-19, junto con el impacto de los huracanes Eta e lota, prolongaron la recesión en 2020, con una caída del crecimiento a $-2.5 \%$. Se estima que el crecimiento se recupere lentamente a $0.9 \%$ para 2021 , según los últimos pronósticos.

Por otro lado, la pandemia ha afectado negativamente al crecimiento económico del país, debido a la creciente incertidumbre sobre la evolución de la crisis sanitaria, la propagación interna del virus, los cierres voluntarios del sector privado, las salidas de capital, la pérdida de puestos de trabajo y la caída del turismo. Como resultado, el progreso logrado en la reducción de la pobreza desde 2005 ha sido detenido. La pobreza, definida como vivir con un ingreso inferior a $\$ 3.2$ por persona por día (en términos de paridad del poder adquisitivo -PPP de 2011), se estima que ha aumentado de $13.5 \%$ en 2019 a $14.7 \%$ en 2020, lo que suma aproximadamente 90,000 personas a la pobreza.

Las remesas incrementaron un $12.1 \%$ en 2019 , con lo que sirvieron para apoyar el consumo de los hogares y mitigaron el aumento de la pobreza. La pandemia tuvo un impacto negativo en las remesas al comienzo de la crisis, lo que provocó una disminución promedio del 3.0 \% entre marzo y abril de 2020. Pero nos recuperamos rápidamente, lo que resultó en una tasa de crecimiento anual en 2020 del $10 \%$. Sin embargo, el hecho de el país tenga una fuerte inversión social, ha beneficiados a las y los nicaragüenses en la prevención y control de la pandemia de coronavirus, para que tengamos una idea, desde el año 2007, hasta el 2021, se han construido 18 hospitales: 15 primarios, 1 departamental y 2 nacionales, todos ellos funcionando gratuitamente y con las condiciones sanitarias para el tratamiento y control del coronavirus, misma que es la más baja de Centroamérica.

A mediano plazo, se proyectó construir 15 hospitales más, aparte de los 18 ya construidos. Seis de los nuevos hospitales ya están en construcción, entre ellos dos grandes: el de León y el de Nueva Segovia. También está proyectado el hospital Nuevo Amanecer en la Costa Caribe Norte, el primero en el Caribe. Dos hospitales primarios: uno en El Cuá, y otro en Matiguás, con un costo de alrededor de los 6 y 7 millones de dólares. El de El Cuá está construido en cerca del 100 por ciento, ya se están instalando equipos y haciendo pruebas. También, hay 3 hospitales que están en licitación: el hospital primario en Quilalí, el hospital de Los Chiles en Río San Juan, y el Hospital de Nueva Segovia, en Jalapa y en Masaya.

Asimismo, en la actualidad según la revista Forbes (2018), Nicaragua esta mucho mejor que hace 12 años, porque se han logrados cambios radicales, como avanzar, según el índice de Competitividad Global del Foro Económico Mundial (WEF), el país ocupa uno de los puestos más privilegiados al ser nombrado uno de las naciones con las mejores carreteras de América, dentro de los primeros siete puestos. Al mismo tiempo, el apartado "De Quality of roads" a nivel mundial, Nicaragua ocupa el puesto número 54, arriba de los países de la región centroamericana.

Nicaragua ya no es la cenicienta de la región en términos de desarrollo humano, los indicadores sociales, económicos, culturales y político, nos indican que la llamada segunda independencia, es una realidad consumada, fueron 200 largos años de robo, saqueo e invasiones, de potencias foráneas como fueron los 
españoles, británicos y después los estadounidenses, que hasta el sol de hoy, quieren continuar ejerciendo su dominación contra la sociedad nicaragüense, no obstante, estos últimos 15 años el Frente Sandinista de Liberación Nacional, ha sabido reivindicar la segunda independencia del Estado nacional, asumiendo agendas complejas internas y debatiendo soberanamente el presupuesto general de la republica y sabiendo invertir en infraestructura urbana y rural para desarrollar el país centroamericano.

Sin embargo, hasta los momentos se le critica fuertemente el tortuguismo con el que esta trabajando las autoridades en los cansos del saneamiento de los territorios indígenas del caribe sur, norte y las regiones especiales de Jinotega, donde los pueblos indígenas siguen sufriendo la expansión del campesino de la frontera agrícola en la reserva de biosfera BOSAWAS, particularmente en la comunidad de Wina y KiwaKumbaih en Musawas, donde los Gobiernos Territoriales Indígenas, siguen demandándole al Estado de Nicaragua, ponga un freno a los colonos armados, que siguen deforestando, expandiendo la frontera agrícola y, promoviendo la extracción de broza u lavando oro, que termina contaminando el rio Wuaspuk y Wangky.

La invasión de colonos en los territorios tradicionales y ancestrales de los indígenas, debido a su cantidad y a la impunidad con la que actúan, ha rodeado los asentamientos principales de las comunidades; por lo que las personas indígenas temen salir de sus casas a cultivar o a recoger las cosechas, a pescar o a cazar para obtener sus alimentos causándoles algosa grados de desnutrición y pobreza-; mientras los bosques han sido deforestados para sembrar pasto para la ganadería extensiva que realizan los colonos y por algunas empresas como Alba Forestal; pero más recientemente, y ahora con este ataque, los indígenas ya no se sienten seguros ni dentro de sus propias casas.

Lamentan los líderes indígenas que todo esto pase a pesar que el Batallón Ecológico del Ejército de Nicaragua se encuentra en Bosawás con la misión de proteger la Reserva, mientras los colonos en total impunidad se apoderan de su patrimonio ancestral, histórico y cultural; contaminan los ríos esenciales para el consumo humano de agua con sus actividades causan la pérdida de biodiversidad, flora y fauna degradando así los medios de vida de los indígenas y la Reserva de Bosawás. Por lo que los líderes indígenas refieren sentirse amenazados por la autoridades territoriales, municipales, regionales y nacionales, al omitir brindarles la seguridad necesaria ante los ataques de los colonos.

Peor aún, los líderes indígenas detuvieron recientemente a un grupo de colonos que se encontraban dentro de su territorio, los colonos acusaron al Presidente y a otros miembros del Gobierno Territorial Indígena (GTI) del Territorio Mayangna Sauni As de haberles dado permiso para entrar en las tierras indígenas a cambio de dinero; así como también tienen en su poder documentación donde el Presidente del GTI otorga tierra a un familiar del mismo en violación a las Leyes No. 28 y 445; por lo que actualmente están citando para en una asamblea extraordinaria (Asanglawana) para elegir nuevas autoridades. Sin embargo, ya en otras ocasiones el Consejo Regional de la RACCN solo certifica a autoridades afines al partido político actualmente en el gobierno. 


\section{Conclusiónes.}

El festejo de la independencia en Nicaragua entre 1866 y 1895, fue una celebración que tuvo un carácter exclusivo debido a que se realizaba en el salón de Congreso y al cual asistía la élite político económica. Su centro de celebración fue la ciudad de Managua, centro neurálgico y coordinador de la economía agrícola nacional, aunque al final del período de estudio otros centros económicos importantes del país comienzan a festejar esta fecha patria, promoviendo también la identidad agrícola que el Estado desarrollaba.

Los contenidos políticos que se transmitieron en estos actos, se pueden dividir en dos períodos, el primero corresponde a los años de 1866 a 1875, donde la independencia había traído la igualdad entre los nicaragüenses, pero estos debían de moralizarse, practicar el patriotismo y el trabajo con el fin de cimentar la estabilidad política. Asimismo, se añoraba la llegada de la unión centroamericana. Entre 1877 y 1895 los discursos conmemorativos del 15 de setiembre añaden conceptos políticos que destacaban el papel "liberador" de la educación. Promovían la unidad nacional y la regeneración étnica de los nicaragüenses, pues se rescata el protagonismo del héroe nacional José Dolores Estrada y de la Campaña Nacional. Asimismo, se exalta el progreso económico y la estabilidad política traída por los gobiernos conservadores.

Estas peroraciones también sirvieron para manifestar una visión clasista y mantener la forma de dominación imperante. Durante el siglo XIX la mayor parte de la población nicaragüense vivía en condiciones de analfabetismo, miseria y aislamiento y no tenía acceso al poder. Estos discursos legitimaron las abismales diferencias sociales y económicas creadas por los conservadores, poniendo como remedio a la crisis del pacto oligárquico el uso del trabajo forzado entre los campesinos. El trabajo era la panacea del cual se derivaban la educación y el bienestar, elementos indispensables para que en Nicaragua se asentara la libertad. La iglesia católica dentro de su papel de institución subordinada al Estado, también, participó en la celebración de la independencia emitiendo dos discursos, en el primero señalaba que esta era un regalo de Dios y en el segundo promovía la unión centroamericana.

Los textos emitidos por los intelectuales nicaragüenses en la prensa sobre las celebraciones del 15 de setiembre durante el período 1903-1928, son, a nivel general, del tipo nacionalista, debido a que hablan en nombre del conjunto de la colectividad a la cual dicen representar, lo que les da un carácter inclusivo. Ellos exponen las diversas influencias político-culturales que existían en la intelectualidad de esa época para abordar el tema de la identidad nacional y analizar los principales problemas por los que atravesaba Nicaragua, principalmente el de la ocupación estadounidense. Transitan entre una postura nacionalista y una antiimperialista. En estos discursos se publicaron conceptos que van desde la conservación histórica de esta fecha, la preservación de los rasgos identitarios de los nicaragüenses, el papel de la Batalla de San Jacinto en la exaltación de la imagen de los nicaragüenses como conjunto social, el papel del faccionalismo político y las ansias de poder de los partidos Liberal y Conservador, la influencia de esto en la degeneración sociopolítica de Nicaragua. Luego de 1928 parecerá el efecto del Ejército Defensor de la Soberanía Nacional, y su máximo líder Augusto Sandino, quien lucharía hasta el ultimo días se su vida contra los marines, lográndolo derrotarlo y expulsarlo del país en 1933. Luego de la traición al heroico general de hombres y mujeres libres en 1934, pasaría años en la carrera, para volver a liberar a Nicaragua del domino del imperialismo norteamericano, hasta el triunfo de la revolución popular sandinista el 19 de julio de 1979, que a la postre, se convirtió en nuestra segunda independencia, de cualquier potencia externa que quiera controlar la política del país centroamericano, sin embargo, desde 1980 hasta 1990, el imperialismo estadounidense nos impuso un bloqueo y una larga guerra contrarrevolucionaria que le constaría grandes perdidas humanas y materiales al país. 


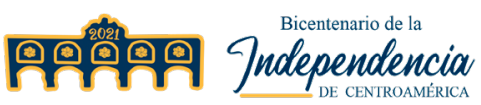

\section{Referencias bibliográficas.}

- $\quad$ Bagú, Sergio. (1975). “Tres oligarquías, tres nacionalismos”. Cuadernos Políticos. Núm. 3.

- Bertoni, Lilia. (1992). "Construir la nacionalidad: Héroes, estatuas y fiestas patrias, 1887-1891". Boletín del Instituto de Historia Argentina y Americana Dr. E. Ravignani. Núm. 5. Buenos Aires: FCE.

- Blázquez, Gustavo. (2000). “El Juramento, perdón... la promesa a la Bandera de los Argentinos. Actos escolares y violencia sémica". VI Congreso Argentino de Antropología Social, Mar del Plata.

- CEPAL. (2002). Centroamérica: el impacto de la caída de los precios del café. México: Comisión Económica para América Latina.

- CEPAL. (2018). La inversión extranjera directa en América Latina y el Caribe. México: Comisión Económica para América Latina.

- CIAV-OEA. (1998). La desmovilización y reinserción de la Resistencia Nicaragüense. Estados Unidos: CIAV-OEA.

- $\quad$ Cruz O. Paul (2019) Frontera Agrícola, Movimientos Campesinos e Indígenas del Norte de Nicaragua “De los Milpas y Chilotes a los Autoconvocados", revista Raíces Unan Managua.

- Collado H., María del Carmen. (1988). "Liberales y conservadores de Nicaragua ¿falsos estereotipos?" Secuencia. Núm.11.

- Close, David. (2005). Los años de doña Violeta. La historia de la transición política. Nicaragua: Lea Grupo Editorial.

- Cumberland, W.W. (1978). Nicaragua: investigación económica y financiera. Managua: Colección Cultural Banco de América.

- Delgado, José Salomón. (1974). “Unidades de producción más importantes durante el período de los 30 años conservadores (hacienda tradicional y la mano de obra)". Anuario de Estudios Centroamericanos. Núm.1. San José: Universidad de Costa Rica. Diario de Nicaragua, 18 de septiembre de 1895.

- Díaz Arias, David. (2007). “Entre la guerra de castas y la ladinización. La imagen del indígena en la Centroamérica liberal, 1870-1944". Revista de Estudios Sociales. Universidad de los Andes, Colombia. Num.26.

- Díaz Arias, David. (2011).“Pequeños patriotas y ciudadanos. Infancia, nación y conmemoración de la independencia en Costa Rica, 1899-1932". Araucaria. Vol.13. Núm. 25.

- Donoso Romo, Andrés. (2010). “La nación como protagonista de la educación en América Latina 1870-1930". Revista Historia de la Educación Latinoamericana. Universidad Pedagógica y Tecnológica de Colombia. Núm. 14. 
- $\quad$ Eric Wolf (1982). Europa y La Gente sin Historia. Fondo de Cultura Economica, Mexico. 254 copias.

- $\quad$ Fernández. P. (diciembre del 2010). Mujer y trabajo rural. Reflexiones en torno a la Revolución Sandinista. Revista del Programa de Investigaciones sobre Conflicto Social.

- Gould Jeffrey L. (1993) El Café, El trabajo y la Comunidad Indígena de Matagalpa, 1980-1925.

- Gould Jeffrey L. (1997) El Mito de la Nicaragua Mestiza y la Resistencia Indígena de 1880-1980., San José, Costa Rica.

- Kinloch. F. (2009). Historia de Nicaragua 3ra Edición,. Managua.

- $\quad$ El Comercio, 17 de septiembre de 1903.

- $\quad$ El Comercio, 14 de septiembre de 1906.

- $\quad$ Escobar, Esteban. (1968). "El libro del mes: Biografía del General Pedro Joaquín Chamorro". Revista Conservadora del Pensamiento Centroamericano. Vol.92.

- $\quad$ Esgueva Gómez, Antonio. (1999). Conflictos y paz en la Historia de Nicaragua. Managua: Instituto de Historia de Nicaragua y Centroamérica-Universidad Centroamericana.

- $\quad$ Fernández Ampié, Guillermo. (2008). Variaciones de la idea de nación y patria en los textos escolares de Historia de Nicaragua. 1871-1930: El arduo camino en la construcción del sentimiento de nacionalidad nicaragüense.

- $\quad$ Rueda Estrada, Verónica. (2013). El Campesinado migrante. Políticas agrarias, colonizaciones internas y movimientos de frontera agrícola en Nicaragua 1960-2012. Tzintzun, Revista de Estudios Históricos, 57, 155-198.

- Rueda Estrada, Verónica. (2015). Recompas, recontras, revueltos y rearmados. Posguerra y conflictos por la tierra en Nicaragua. México: Instituto Mora-UNAM.

- UNOs contra UNOs: Región V en rebelión (diciembre de 1990). Envío. Información sobre Nicaragua y Centroamérica, 110. Recuperado de http://www.envio.org.ni/articulo/647.

- Vilas, Carlos. (1994). Mercado, estados y revoluciones. Centroamérica 1950-1990. México: Centro de Investigaciones Interdisciplinarias en Ciencias y Humanidades (CEIICH)-Universidad Nacional Autónoma de México (UNAM).

- Vivas Viachica, Elgin Antonio. (2007). Migración interna en Nicaragua: descripción actualizada e implicancias de política, con énfasis en el flujo ruralurbano. Chile: CEPAL-UNFPA-CELADE. 